\title{
Seasonal variation in acute variceal upper gastrointestinal tract bleeding: Experience of one decade from Northern India
}

\author{
Shabir Ahmad Shiekh¹, Ali Imran², Showkat Ahmad Kadla ${ }^{3}$, Mohammad Yasin ${ }^{4}$, \\ Bilal Ahmad Khan ${ }^{5}$, Zeeshan Ahmad Wani', Nisar Ahmad Shah ${ }^{7}$ \\ 1,4,5,6,7 Consultant, Department of Gastroenterology and Hepatology, Government Medical College Srinagar Kashmir \\ India, ${ }^{2}$ Consultant, Critical Care Medicine, Sher-I-Kashmir Institute of Medical Sciences, Srinagar Kashmir India, \\ ${ }^{3}$ Professor and Head, Department of Gastroenterology and Hepatology, GMC Srinagar Kashmir India
}

\section{A B S T R A C T}

Background: There have been several reports of seasonal variations in the incidence of esophageal variceal bleeding but the data available from this part of the world is scanty. Aims and Objective: We aimed to study whether monthly and seasonal climatic changes during the year have an influence on the incidence of variceal bleeding in our setting and whether a particular time in the year can be defined as a high-risk period for variceal bleed. Materials and Methods: Data of all the patients with diagnosis of acute variceal upper gastrointestinal bleed who presented to our endoscopy centre from January 2010 to December 2019 was retrieved and analysed. The demographic data, clinical presentations and seasonal and monthly variation was analysed. Results: Out of a total of 10200 patients presenting with upper gastrointestinal bleed during the study time period, 530 patients had a diagnosis of variceal bleed after esophagogastroduodenoscopy (EGD). The majority of variceal bleed patients (48.5\%) were seen between May to August months of the year. Conclusions: Contrary to the most of the literature which shows increased frequency of variceal bleed during winters, our patients bleed more during the months of May and August. This could be explained on the basis of unique socio-cultural and demographic pattern of this part of the world.

Key words: Acute variceal upper gastrointestinal bleed (AVUGIB); Varices; Seasonal variation; Upper gastrointestinal bleed (UGI Bleed)

\section{Access this article online}

Website:

http://nepjol.info/index.php/AJMS DOI: 10.3126/ajms.v12i8.36803

E-ISSN: 2091-0576

P-ISSN: 2467-9100

Copyright (c) 2021 Asian Journal of Medical Sciences

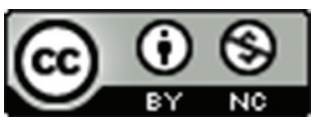

This work is licensed under a Creative Commons Attribution-NonCommercial 4.0 International License.

\section{INTRODUCTION}

Variceal bleeding (VB) constitutes an important decompensating event in the natural history of cirrhosis and its impact differs whether it presents as an isolated complication of cirrhosis ( $20 \% 5$-year mortality) or in association with other complications (over $80 \%$-year mortality). ${ }^{1} \mathrm{VB}$ occurs at a rate of around $10 \%-15 \%$ per year and depends on the severity of liver disease, size of varices and presence of red wale marks (areas of thinning of the variceal wall). ${ }^{2,3}$ Six-week mortality, which is now recognized as the primary endpoint to assess the impact of therapies for acute $\mathrm{VB}$, ranges between $15 \%$ and $25 \% .4,5$
Other factors associated with poor outcomes in patients with $\mathrm{VB}$ are the presence of bacterial infections and an HVPG $>20 \mathrm{~mm} \mathrm{Hg}$, which is mostly observed in patients belonging to the CTP-Cclass. ${ }^{6,7}$

There have been several reports of seasonal variations on the incidence of esophageal variceal bleeding. Although seasonal differences are still controversial, many reports suggest that esophageal variceal bleeding occurs more often in winter.

To our knowledge not much experience is available from our country to address this issue. The aim of this study is to assess whether climatic factors throughout the 12 months 
and 4 seasons of the year have an influence on the incidence of variceal bleeding. Anticipation of such variations in the incidence of (AVUGIB) during a particular time or season of the year might allow primary medical care centres and hospitals to adopt related interventions so as to have a favourable impact on management of patients.

\section{MATERIALS AND METHODS}

This was a retrospective observational study carried out in the Department of Gastroenterology at Government Medical College Srinagar over a period of ten years between January 2010 to December 2019. This is a tertiary care hospital and runs a $24 \times 7$ emergency endoscopy services with round the clock availability of an experienced endoscopy staff.

\section{Inclusion criteria}

Adult patients ( $>18$ years) of either gender with diagnosis of AVUGIB after UGI endoscopy were included in the study. Patients were included irrespective of cause of portal hypertension i.e. both cirrhotic and non-cirrhotic patients were included. In all UGI endoscopy was performed within 24 hours of admission.

Informed consent for endoscopy was obtained by the endoscopy staff before the procedure. EGD was performed in a standard manner with the patient in the left lateral position after topical xylocaine spray/jelly using GIF LV1 and GIF Q150 Video endoscope from Olympus optical Co., $L t d$., Tokyo, Japan. Majority of the procedures were done using intravenous midazolam. Intravenous propofol was used in few cases.

Data extracted from their records included gender, age, patient's demographic and clinical characteristic, the date of admission, the background aetiology of portal hypertension and blood tests including liver and renal function tests and parameters of complete blood count.

Patients were categorized into twelve 1-month intervals and into four 3-month intervals (seasons): winter was defined as January-March, spring as April-June, summer as JulySeptember, and autumn as October-December. The data were analysed according to month and season.

This study protocol was undertaken after being approved by the Institutional Ethical Review Board.

\section{Statistical analysis}

Collected data was compiled and entered in spread sheet Microsoft excel and exported to Data editor of SPSS computer software, version 20 (SPSS Inc., Chicago, IL,
USA). Continuous variables were expressed as mean \pm standard deviation and categorical variables were summarized as frequency and percentage.

\section{RESULTS}

\section{Patients' demographic characteristics}

A total of 10200 patients presented with diagnosis of UGI Bleed to our endoscopy centre between January 2010 to December 2019. Out of them 530 patients were diagnosed as AVUGI Bleed (Table 1).

Two hundred twenty-two (42\%) patients had first episode of variceal bleeding and $58 \%$ of patients had recurrent variceal bleeding episode. There were $54 \%$ males and $46 \%$ females in our study. The mean age was $46.5 \pm 12.7$ years.

Majority of the patients presented in spring (32\%) season followed by summer (30\%) (Table 2). May (16.6\%) had the highest percentage of cases followed by July $(13.2 \%)$ (Table 3).

\section{DISCUSSION}

Variceal bleeding is an important landmark in the natural history of cirrhosis with significant morbidity and mortality. Despite improvement in the management strategies, the mortality can still be as high as $15-30 \%{ }^{4,8}$ Various factors predict higher mortality and re-bleed in variceal bleed like severity of liver disease, Hepatic venous pressure gradient (HVPG) > $20 \mathrm{mmHg},{ }^{9}$ diabetes mellitus and serum bilirubin more than $3 \mathrm{mg} / \mathrm{dl}^{10}$

Besides these factors, seasonal variation in variceal bleeding has been reported in number of studies with majority of them showing higher frequency of gastrointestinal bleed in winter season. ${ }^{11-14}$ Although some literature has refuted any seasonal variation in gastrointestinal bleed. ${ }^{15,16}$

Siddiqui MT et al., ${ }^{11}$ reported a higher frequency of variceal bleeding in December (8.8\%) and January $(8.7 \%)$ compared to a nadir in June $(7.8 \%)$. A retrospective data from Israel ${ }^{12}$ found peak incidence during winter season with significant $\mathrm{p}$-values $(=0.02)$. Thirteen point five percent cases presented during March while as only 5.7 $\%$ cases presented during June. Findings from a Beijing hospital ${ }^{17}$ as well as from an European centre ${ }^{14}$ also found that the cases of variceal bleeding were significantly higher in cold months (December to April) compared to warmer months (June to September). Exposure to low air temperature (LAT) was found to expose patients to a higher risk of variceal bleeding regardless of Child-Pugh 


\begin{tabular}{|c|c|c|c|c|c|}
\hline \multirow{2}{*}{\multicolumn{4}{|c|}{$\begin{array}{l}\text { Total population studied } \\
\text { (AVUGIB cases) }\end{array}$}} & & 530 \\
\hline & & & & \multirow{2}{*}{\multicolumn{2}{|c|}{$222(42 \%)$}} \\
\hline \multicolumn{4}{|c|}{ First episode } & & \\
\hline \multicolumn{4}{|c|}{ Recurrent bleed } & \multicolumn{2}{|r|}{$308(58 \%)$} \\
\hline \multicolumn{6}{|c|}{ Gender } \\
\hline \multicolumn{4}{|c|}{ Male n (\%) } & \\
\hline \multicolumn{4}{|c|}{ Female $\mathrm{n}(\%)$} & \multicolumn{2}{|r|}{$\begin{array}{l}286(54 \%) \\
244(46 \%)\end{array}$} \\
\hline \multicolumn{4}{|c|}{ Age in years (mean $\pm S D$ ) } & \multicolumn{2}{|r|}{$46.5 \pm 12.7$} \\
\hline \multirow{2}{*}{\multicolumn{4}{|c|}{$\begin{array}{l}\text { Etiology of Variceal bleed } \\
\text { NAFLD }\end{array}$}} & \multicolumn{2}{|r|}{$\mathrm{n}(\%)$} \\
\hline & & & & \multicolumn{2}{|r|}{$233(44 \%)$} \\
\hline \multirow{2}{*}{\multicolumn{4}{|c|}{$\begin{array}{l}\mathrm{HBV} \\
\mathrm{HCV}\end{array}$}} & \multicolumn{2}{|r|}{$74(14 \%)$} \\
\hline & & & & \multicolumn{2}{|r|}{$47(9 \%)$} \\
\hline \multicolumn{4}{|l|}{ ALD } & \multicolumn{2}{|r|}{$16(3 \%)$} \\
\hline \multicolumn{4}{|l|}{ EHPVO } & \multicolumn{2}{|r|}{$32(6 \%)$} \\
\hline \multicolumn{4}{|l|}{ Others } & \multicolumn{2}{|r|}{$128(24 \%)$} \\
\hline \multicolumn{6}{|c|}{$\begin{array}{l}\text { AVUGIB: Acute variceal upper gastrointestinal tract bleeding; NAFLD, non-alcoholic } \\
\text { fatty liver disease; HBV, Hepatitis B virus HCV, Hepatitis C virus; ALD, Alcoholic liver } \\
\text { disease; EHPVO Extrahepatic portal venous obstruction }\end{array}$} \\
\hline \multicolumn{6}{|c|}{$\begin{array}{l}\text { Table 2: Distribution of the cases as per the four } \\
\text { seasons }\end{array}$} \\
\hline & Total & Winter & Spring & Summer & Autumn \\
\hline $\begin{array}{l}\text { Frequency } \\
\text { (n) }\end{array}$ & 530 & 73 & 169 & 158 & 130 \\
\hline $\begin{array}{l}\text { Percentage } \\
(\%)\end{array}$ & 100 & 13.77 & 31.88 & 29.81 & 24.52 \\
\hline
\end{tabular}

\begin{tabular}{llcc}
$\begin{array}{l}\text { Table 3: Distribution of the cases on monthly } \\
\text { basis }\end{array}$ & & \\
\hline Season & Month & Frequency (n) & Percentage (\%) \\
\hline Winter & January & 18 & 3.39 \\
& February & 32 & 6.03 \\
& March & 23 & 4.33 \\
Spring & April & 39 & 7.35 \\
& May & 88 & 16.60 \\
& June & 42 & 7.92 \\
Summer & July & 70 & 13.20 \\
& August & 53 & 10.0 \\
\multirow{5}{*}{ Autumn } & September & 35 & 6.60 \\
& October & 53 & 10.0 \\
& November & 21 & 3.96 \\
& December & 56 & 10.56 \\
& Total & 530 & 100 \\
\hline
\end{tabular}

class score, aetiology of liver disease and concomitant HCC. ${ }^{13}$

Although the exact etiopathogenesis remains unknown for this higher risk of variceal bleed during winter months but various physiological and neuro-hormonal factors have been implicated. During winters, a rise in portal pressure and systemic pressures has been found ${ }^{18}$ besides decreased secretion of vasopressin from the posterior pituitary. ${ }^{19}$ Another possible factor could be an increased alcohol and calorie intake during festive winter season.

In our study we observed a different pattern of occurrence of variceal bleeding events. We had most of the cases in spring season followed by summer accounting for 32\% and $30 \%$ respectively. On monthly basis, May $(16.6 \%)$ had the highest percentage of cases followed by July (13.2\%). Winter season (January, February and March combined) accounted for $13.4 \%$ cases only. Cordero FM et al., ${ }^{20}$ also reported that portal hypertension related gastrointestinal bleeding was mostly seen in the months between April and June.

This uneven pattern could be explained on basis of multiple factors. Kashmir is the northern-most part of India covered with an extensive range of mountains. The temperature during winters goes very low with good amount of snowfall leading to closure of many roads during this season which makes access to health care facilities very difficult. Besides there are only two medical centres capable of managing variceal bleed holistically, ours being one of them. Thirdly, there is migration of population especially friable to warmer provinces during winters. Fourthly, increased alcohol intake during festive winter months does not exist as alcohol intake is a religious and social taboo here.

Bacterial infection is an important precipitating factor in many complications of cirrhosis, including variceal bleeding, hepatic encephalopathy, renal failure and coagulation status. ${ }^{21}$ Variceal bleeding is a well-established risk factor for bacterial infection in patients with cirrhosis ${ }^{22}$ and conversely sepsis has been found to increase the risk of variceal hemorrhage. ${ }^{23}$ Multiple factors operate for increased risk of bacterial infection in cirrhosis like liver dysfunction, portosystemic shunting, increased levels of endotoxins, gut dysbiosis, increased bacterial translocation, cirrhosis-associated immune dysfunction, and genetic factors. ${ }^{24,25}$ Endothelins (mostly endothelin-1) released during bacterial infection could also contribute to the initiation of variceal haemorrhage through the induction of cyclo-oxygenase products, ${ }^{26}$ such as thromboxane A2 and prostaglandin F2a.

During late autumn and almost whole of the winter season most of the fragile population including patients with chronic diseases like cirrhotic tend to remain indoors. This accounts for the low level of exposure to various pathogens resulting in low levels of endotoxemia.

\section{CONCLUSIONS}

We believe unique demographic and socio-cultural factors combined with non-uniform health care facilities are responsible for this unique pattern of variceal bleeding in this part of the world. We recommend optimisation 
of management strategies for prophylaxis of variceal bleed such as optimising beta-blocker therapy and variceal ligation could lead to decrease in variceal bleeding and decreased morbidity and mortality in these patients.

\section{ACKNOWLEDGEMENT}

The authors are thankful to the record keeping section at the Gastrointestinal Endoscopy section at GMC Srinagar which is a tertiary care hospital in Srinagar, India.

\section{REFERENCES}

1. D'Amico G, Pasta L, Morabito A, D'Amico M, Caltagirone M, Malizia G, et al. Competing risks and prognostic stages of cirrhosis: a 25-year inception cohort study of 494 patients. Aliment Pharmacol Ther. 2014; 39(10):1180-1193.

https://doi.org/10.1111/apt.12721

2. North Italian Endoscopic Club for the Study and Treatment of Esophageal Varices. Prediction of the first variceal hemorrhage in patients with cirrhosis of the liver and esophageal varices. A prospective multicenter study. N Engl J Med.1988;319:983989. https://doi.org/10.1056/NEJM198810133191505

3. D'Amico G, Pagliaro L and Bosch J. Pharmacological treatment of portal hypertension: an evidence-based approach. Semin Liver Dis. 1999;19(4): 475-505.

https://doi.org/10.1055/s-2007-1007133

4. Reverter E, Tandon P, Augustin S, Turon F, Casu S, Bastiampillai $R$, et al. A MELD-based model to determine risk of mortality among patients with acute variceal bleeding. Gastroenterology. 2014;146(2):412-419. https://doi. org/10.1053/j.gastro.2013.10.018

5. Fortune B, Garcia-Tsao G, Ciarleglio M, Deng Y, Fallon MB, Sigal S, et al.; Vapreotide Study Group. Child- Turcotte-Pugh Class is best at stratifying risk in variceal hemorrhage: analysis of a U.S. multi-center prospective study. J Clin Gastroenterol. 2016; 24. https://doi.org/10.1097/MCG.0000000000000733

6. Tandon P, Abraldes JG, Keough A, Bastiampillai R, Jayakumar S, Carbonneau $\mathrm{M}$, et al. Risk of bacterial infection in patients with cirrhosis and acute variceal hemorrhage, based on Child-Pugh class, and effects of antibiotics. Clin-Gastroenterol Hepatol. 2015;13(6):1189-1196.

https://doi.org/10.1016/j.cgh.2014.11.019

7. Abraldes JG, Villanueva C, Banares R, Aracil C, Catalina MV, GarciAP, et al. Hepatic venous pressure gradient and prognosis in patients with acute variceal bleeding treated with pharmacologic and endoscopic therapy. J Hepatol. 2008;48(2):229-236. https:// doi.org/10.1016/j.jhep.2007.10.008

8. Kim YD, Cheon GJ, Kim MY, Suk KT, Baik SK and Kim DJ. Changes in the clinical outcomes of variceal bleeding in cirrhotic patients: a 10-year experience in Gangwon province, South Korea. Gut Liver. 2012; 6:476-481.

https://doi.org/10.5009/gnl.2012.6.4.476

9. Monescillo A, Martinez-Lagares F, Ruiz-del-Arbol L, Sierra A, Guevara C, Jimenez C, et al. Influence of portal hypertension and its early decompression by TIPS placement on the outcome of variceal bleeding. Hepatology. 2004; 40(4):793-801. https://doi.org/10.1002/hep.20386

10. Majid S, Azam Z, Shah H A, Salih M, Hamid S, Abid S, et al. Factors determining the clinical outcome of acute variceal bleed in cirrhotic patients; Short Report: Indian J Gastroenterol. 2009; 28(3): 93-95.

https://doi.org/10.1007/s12664-009-0034-z

11. Siddiqui MT, Bilal M, Haq KF, Nabors C, Schorr-Lesnick B, Wolf DC, et al. Seasonal impacts on the incidence of esophageal variceal hemorrhage: a nationwide analysis across a decade. Clin Endosc. 2020; 53:189-195.

https://doi.org/10.5946/ce.2019.094

12. Elias S, Wisam S, Masad B, Gali L and Assy Nimer A. Seasonal Patterns of Acute Esophageal Variceal Bleeding in Patients with Liver Cirrhosis. Japanese Journal of Gastroenterology and Hepatology.2020; V3(1): 1-6.

13. Wu WC, Chen YT, Chen PH, Su CW, Huang WM, Yang TC, et al. Low air temperature increases the risk of oesophageal variceal bleeding: a population and hospital-based case-crossover study in Taiwan. Liver Int. 2016; 36: 856-864. https://doi.org/10.1111/liv.12930

14. Boulay F, Berthier F, Dahan MDC and Tran A. Seasonal variations in variceal bleeding mortality and hospitalization in France. Am J Gastroenterol. 2001; 96: 1881-1887. https://doi. org/10.1111/j.1572-0241.2001.03889.x

15. Nomura T, Ohkusa T, Araki A, Chuganji $\mathrm{Y}$, Momoi M, Takashimizu I, et al. Influence of climatic factors in the incidence of upper gastrointestinal bleeding. J Gastroenterol Hepatol. 2001; 16: 619-623. https://doi.org/10.1046/j.1440-1746.2001.02486.x

16. Lopez-Cepero JM, Lopez-Silva ME, Amaya-Vidal A, AlcarazGarcia S, Cayon-Blanco M, Castro T, et al. Influence of climatic factors on the incidence of upper gastrointestinal bleeding. Gastroenterol Hepatol. 2005; 28: 540-545. https://doi.org/10.1157/13080601

17. Tengda $\mathrm{Xu}$, Lingjie $\mathrm{Xu}$, Wang $\mathrm{H}, \mathrm{Xu} \mathrm{J}$, Bohn $\mathrm{HH}, \mathrm{Xu}$, et al. Circadian and seasonal rhythms of acute upper gastrointestinal bleeding in Beijing. Emerg Med J. 2010;27: e504- e507. https:// doi.org/10.1136/emj.2009.075820

18. Brennan PJ, Greenberg G, Miall WE and Thompson SG. Seasonal variation in arterial blood pressure. Br Med J (Clin Res Ed). 1982; 285: 919-923. https://doi.org/10.1136/bmj.285.6346.919

19. Jasnic N, Dakic T, Bataveljic D, Vujovic P, Lakic I, Jevdjovic T, et al. Distinct vasopressin content in the hypothalamic supraoptic and paraventricular nucleus of rats exposed to low and high ambient temperature. J Therm Biol. 2015; 52:1-7. https://doi.org/10.1016/j.jtherbio.2015.04.004

20. Cordero FM, Aguilar EM, Teves PM and Salgado EM. Seasonal variation in upper gastrointestinal bleeding associated with portal hypertension. Rev Gastroenterol Peru. 2006; 26(3):278-282.

21. Thalheimer $U$, Triantos $C K$, Samonakis DN, Patch $D$ and Burroughs AK. Infection, coagulation, and variceal bleeding in cirrhosis. Gut. 2005; 54: 556-563. https://doi.org/10.1136/gut.2004.048181

22. Bernard B, Grangé JD, Khac EN, Amiot X, Opolon P and Poynard T. Antibiotic prophylaxis for the prevention of bacterial infections in cirrhotic patients with gastrointestinal bleeding: a meta-analysis. Hepatology. 1999; 29:1655-1661. https://doi.org/10.1002/hep.510290608

23. Goulis $J$, Patch $D$ and Burroughs AK. Bacterial infection in the pathogenesis of variceal bleeding. Lancet. 1999; 353:139-142. https://doi.org/10.1016/S0140-6736(98)06020-6

24. Mookerjee RP, Stadlbauer V, Lidder S, Wright GA, Hodges SJ, Davies NA, et al. Neutrophil dysfunction in alcoholic hepatitis superimposed on cirrhosis is reversible and predicts the outcome. Hepatology. 2007; 46:831-840. 
https://doi.org/10.1002/hep.21737

25. Wasmuth HE, Kunz D, Yagmur E, Timmer- Stranghoner A, Vidacek D, Siewert E, et al. Patients with acute on chronic liver failure display "sepsis-like" immune paralysis. J Hepatol. 2005; 42:195-201. https://doi.org/10.1016/j.jhep.2004.10.019

26. Yamamoto S, Burman HP, O.Donnell CP, Cahill PA and Robotham JL. Endothelin causes portal and pulmonary hypertension in porcine endotoxemic shock. Am J Physiol. 1997; 27:H1 239-249.

\section{Authors Contribution:}

SAS, BAK, SAK - Concept and design of the study; prepared first draft of manuscript; SAS, SAK, MYM, NAS, BAK, ZAW - Interpreted the results; reviewed the literature and manuscript preparation; SAS, MYM - Concept, coordination, review of literature and manuscript preparation; SAS, BAK, SAK - Statistically analysed and interpreted, preparation of manuscript and revision of the manuscript. All the authors approved the final version of the article for publication.

Work attributed to:

Department of Gastroenterology and Hepatology GMC Srinagar Kashmir India.

Orcid ID:

Dr Shabir Ahmad Shiekh - (1) https://orcid.org/0000-0002-4646-0673

Source of Support: Nil, Conflict of Interest: None declared. 